\title{
NiEMIECKA MEDYCYNA ROMANTYCZNA (1797-1848) W OPINIACH PRZEDSTAWICIELI POLSKIEGO ŚRODOWISKA NAUKOWEGO DO 1863 ROKU
}

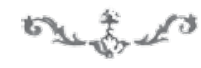

IEmiecka medycyna romantycznA ${ }^{1}$ jest problemem niemal zupełnie
nieznanym polskim humanistom. Do 1989 roku temat ten nie istniał także w polskiej historiografii medycyny, nie było również znane to pojęcie, co może dziwić na tle trwałej obecności romantycznej tradycji w polskiej kulturze intelektualnej XX stulecia zarówno na poziomie akademickim, jak i popularnym ${ }^{2}$. Możliwość zapoznania się z poświęconym tej problematyce piśmiennictwem niemieckim zrodziła się dopiero w latach dziewięćdziesiątych $\mathrm{XX}$ wieku, kiedy to, $\mathrm{z}$ jednej strony znacznemu poszerzeniu uległa oferta stypendialna dla polskich naukowców, zamierzających podjąć badania nad historią nauki niemieckiej ${ }^{3}$, a $\mathrm{z}$ drugiej - w polskiej historiografii nastąpiła zmia-

1 Por. B. Płonka-Syroka, Niemiecka medycyna romantyczna, Warszawa 2007.

2 Por. taż, Stereotyp romantyzmu $w$ historiografii $i$ świadomości potocznej-analiza wybranych elementów, w: Sztuka interpretacji, pod red. B. Czajkowskiego, Wrocław 2006, s. 97-112; taż, Elementy romantycznego standardu racjonalności w kulturze wspótczesnej, w: Tradycja: wartości i przemiany, pod red. J. Adamowskiego i J. Styka, Lublin 2009, s. 123-133.

3 Na początku lat dziewięćdziesiątych XX wieku uzyskałam stypendia naukowo-badawcze DAAD i DFG, umożliwiające pobyt w niemieckich instytutach naukowych, a następnie - na podstawie wstępnie przeprowadzonych badań - grant KBN dotyczący historii medycyny niemieckiej pierwszej połowy XIX wieku, zakończony publikacją Medycyna niemiecka nurtu niematerialistycznego (1797-1848) i polska recepcja jej teorii i doktryn $w$ dziewiętnastym stuleciu (Warszawa 1999). W publikacji znajduje się obszerna bibliografia dotycząca problemu niemieckiej medycyny romantycznej, przedstawiona przeze mnie w ujęciu analitycznym i chronologicznym. W dalszych przypisach 
na teoretycznego standardu, umożliwiająca publikację prac nawiązujących do metodologii konstruktywizmu historycznego 4 i pozostających pod wpływem niemieckiej metodologii badań kulturowych ${ }^{5}$. Cechą nowego standardu prac $\mathrm{z}$ historiografii medycyny w Polsce po 1989 roku stało się uwzględnianie elementów zewnętrznego otoczenia nauk medycznych zarówno politycznego, ekonomicznego, jak i kulturowego, w standardzie prac poświęconych medycynie jako takiej. Przedmiotem badań stało się odtąd społeczeństwo, w którym jedną z form świadomości jest medycyna, a nie - jak wcześniej - medycyna oderwana od wszelkich związków z otaczającą ją kulturą umysłową epoki. W tym właśnie nurcie znajdują się moje badania nad fenomenem niemieckiej

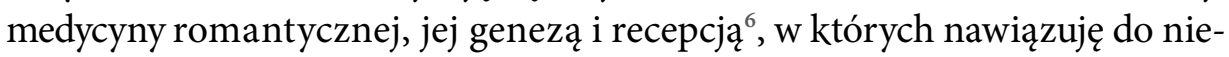
mieckiej metodologii badań kulturowych ${ }^{7}$, umożliwiającej analizę struktur wiedzy, które ze współczesnego punktu widzenia nie spełniają kryterium wiedzy racjonalnej (choć w epokach dawnych miały taki status) ${ }^{8}$. W moich badaniach akceptuję aktywną rolę indywidualnych podmiotów poznających ${ }^{9}$, skupiających się w szkoły naukowe ${ }^{10}$. Na ich światopogląd naukowy wpływają

do niniejszego artykułu przedstawiam liczne publikacje mojego autorstwa dotyczące niemieckiej medycyny romantycznej i jej ujęcia w historiografii. Problematyka ta nie była jak dotąd podejmowana przez innych polskich historyków medycyny.

4 Por. B. Płonka-Syroka, Kształtowanie się standardu metodologicznego polskiej historiografii po transformacji ustrojowej. Próba analizy, w: Perspektywy poznawcze w kulturze europejskiej. Studium porównawcze, pod red. B. Płonki-Syroki i E. Rudolf, Wroclaw 2012, s. 65-87.

5 Por. taż, Medycyna w historii i kulturze. Studia z antropologii wiedzy, Wrocław 2013, s. 23-140.

6 Por. taż, Romantyzm w medycynie niemieckiej $w$ świetle badań rodzimej historiografi $z$ lat 1802-1945, „Medycyna Nowożytna. Studia nad Historią Medycyny” 1998, z. 2, s. 11-54; taż, Obraz medycyny niemieckiej z lat 1797-1848 w piśmiennictwie z drugiej połowy XX stulecia. Próby określenia głównych cech epoki oraz jej struktury, w: B. Płonka-Syroka, Medycyna niemiecka nurtu niematerialistycznego..., s. 59-121.

7 Por. taż, Społeczno-kulturowy kontekst historii medycyny - przegląd koncepcji i propozycje badawcze, „Medycyna Nowożytna. Studia nad Historią Medycyny” 1995, z. 1, s. 5-22; taż, Problem przemian w medycynie europejskiej XVI-XIX wieku w świetle wybranych koncepcji z zakresu metodologii historii nauki, „Medycyna Nowożytna. Studia nad Historią Medycyny" 1997, z. 1-2, s. 5-38.

8 Por. taż, Niemiecka medycyna romantyczna (1797-1848) jako problem badawczy, „Kwartalnik Historii Nauki i Techniki” 1997, nr 1, s. 21-42; taż, Kierunki teoretycznego uzasadniania terapii w medycynie niemieckiej pierwszej połowy XIX stulecia, „Kwartalnik Historii Nauki i Techniki” 1997, nr 2, s. 69-86.

9 Por. taż, Problem wyboru teorii przez społeczność naukowa na przykładzie nauk medycznych, „Prace Naukowe Wyższej Szkoły Pedagogicznej w Częstochowie. Filozofia i Socjologia" 1995, s. 177-193.

10 Por. taż, Teorie, doktryny i szkoły medyczne. Zarys zagadnienia, „Kwartalnik Historii Nauki i Techniki” 1998, nr 1, s. 51-75. 
w sposób trwały elementy kulturowe znajdujące odbicie w strukturze tworzonej przez nie wiedzy ${ }^{11}$, odnoszonej do pewnej wizji świata, uznawanego przez daną szkołę naukową za faktyczną ${ }^{12}$. Podłoże kulturowe, a nie konkretne kwestie kliniczne, było przyczyną wyróżnienia w niemieckiej medycynie klinicznej dwóch rywalizujących ze sobą nurtów modernizacyjnych: naturalistycznosomatycznego ${ }^{13}$ i romantycznego ${ }^{14}$, jak również zróżnicowania teoretycznego i praktycznego w specjalnościach klinicznych ${ }^{15}$. Szersze przedstawienie piśmiennictwa poświęconego problematyce niemieckiej medycyny romantycznej, jak również metodologii badań, znajduje się w publikacjach zamieszczonych w przypisach do niniejszego artykułu ${ }^{16}$. Jego celem jest krótkie omówie-

11 Por. taż, Imputacje kulturowe w kształtowaniu się obrazu natury w myśli europejskiej od XVI do końca XIX wieku. Zarys zagadnienia, w: Człowiek wobec natury - humanizm wobec nauk przyrodniczych, pod red. J. Sokolskiego, Warszawa 2010, s. 207-236.

12 Por. taż, Imputacje kulturowe w standardzie niemieckiej medycyny romantycznej, w: Antropologia medycyny i farmacji w kontekście społecznym i historycznym, pod red. B. Płonki-Syroki, Wrocław 2008, s. 313-331; taż, Niemiecka medycyna romantyczna w perspektywie badań kulturowych nad historia nauk przyrodniczych, w: Obrazy świata jako konstrukty kultury. Analiza historyczno-porównawcza, pod red. B. Płonki-Syroki i A. Syroki, Wrocław 2012, s. 107-120; taż, Standard racjonalności pruskiej medycyny akademickiej w latach 1797-1848, w: Katowice. W 142 rocznice uzyskania praw miejskich, pod red. A. Barciaka, Katowice 2008, s. 192-203.

13 Por. taż, Christoph Wilhelm Hufeland jako pionier profilaktyki medycznej i medycyny społecznej w niemieckiej myśli medycznej przełomu XVIII i XIX wieku, w: Idea opieki a zasada równości i wolności, pod red. W. Wójcika, P. Dancaka i A. Wąsińskiego, Bielsko-Biała 2012, s. 79-103.

14 Por. taż, Doktryny medyczne nurtu hermetycznego - struktura, geneza, uwarunkowania recepcji w społeczności naukowej, „Medycyna Nowożytna. Prace historycznomedyczne” 1992 (zeszyt wstępny), s. 7-38; taż, Różne koncepcje podmiotowości człowieka w teoriach $i$ doktrynach medycznych, „Medycyna Nowożytna. Studia nad historią medycyny” 1996, z. 1-2, s. 23-50; taż, Koncepcja podmiotowości człowieka wobec podstawowych pojęć medycyny teoretycznej i praktycznej, „Kwartalnik Historii Nauki i Techniki” 1998, nr 2, s. 65-76.

15 Por. taż, Spory o kształtowanie się standardu nowoczesnej psychiatrii w XIX stuleciu, „Kwartalnik Historii Nauki i Techniki” 2002, z. 1, s. 1-23; taż, Niemiecka psychiatria romantyczna - spór o wplywy idealizmu filozoficznego w niemieckiej medycynie klinicznej pierwszej połowy XIX stulecia, w: Społeczno-ideowe aspekty medycyny i nauk przyrodniczych XVIII-XX wieku, pod red. B. Płonki-Syroki, Wrocław 2002, s. 103-113; taż, Imputacje kulturowe w standardzie niemieckiej psychiatrii klinicznej w pierwszej połowie XIX wieku, w: Kulturowe przedstawienia psychiatrii i chorób psychicznych / Cultural representations of psychiatry and mental illness, pod red. K. Szmigiero, Piotrków Trybunalski 2009, s. 209-220.

16 Por. też: taż, Głód prawny i obiektywnej pewności. Przykład niemieckiej medycyny romantycznej 1797-1848, w: Głód: skojarzenia, metafory, refleksje, pod red. K. Łeńskiej-Bąk, Opole 2014, s. 189-205; taż, Spór o model medycyny klinicznej w Europie (1750-1850): 
nie niemieckiej medycyny romantycznej jako odosobnionego nurtu w europejskiej medycynie klinicznej pierwszej połowy XIX wieku oraz przedstawienie jego recepcji w nauce polskiej.

Pojęcie niemieckiej medycyny romantycznej zostało wprowadzone do historiografii medycyny w drugiej połowie XIX wieku i miało charakter epitetu deskrybującego takie cechy jej standardu, jak irracjonalizm, oparcie na metafizycznych i filozoficznych spekulacjach, brak kryteriów falsyfikowalności, zamknięcie się na pojawiające się w głównym nurcie klinicznym innowacje teoretyczne i praktyczne oraz rażąca na tle innych krajów europejskich nieskuteczność. Niematerialistyczny standard medycyny niemieckiej z lat 1797-1848 określały także po 1850 roku takie pojęcia, jak Naturphilosophische Medizin, Medizin der Goethezeit albo Philosophische Medizin. Teoretyczną podbudową tych pojęć był pozytywizm, uznający obecność wpływów filozofii i religii w standardzie przyrodoznawstwa za przyczynę błędów, do których usunięcia należało zmierzać i uważano to nie tylko za konieczne, lecz także możliwe. Tym bardziej krytycznie odnoszono się do stwierdzanych w medycynie wpływów kulturowych o charakterze literackim czy artystycznym, toteż określenia „medycyna romantyczna” lub „medycyna czasów Goethego” miały podkreślać brak profesjonalizmu u akceptujących ten standard lekarzy, podporządkowywanie się przez nich marzeniom i iluzjom, ogólnie biorąc - myślenie życzeniowe, biorące własne przekonania za prawdę.

Na przełomie XIX i XX wieku pojęcie „medycyna romantyczna” zdobyło sobie przewagę wśród innych i utrwaliło w niemieckiej historiografii na określenie epoki między 1797 a 1848 rokiem, w której jej standard był aktywnie narzucany środowiskom uniwersyteckim przez władze, napotykając mniej lub bardziej zdecydowane protesty niemieckich lekarzy. Z perspektywy półwiecza - od usunięcia przez władze państwowe standardu medycyny romantycznej z niemieckich uniwersytetów i zastąpienia go ogólnoeuropejskim standardem klinicznym - coraz bardziej zaczęła ukazywać się złożoność tej epoki.

Francja, Austria i Prusy - odmienne warianty modernizacji, w: Zatargi, waśnie, konflikty w perspektywie historycznej i kulturowej, pod red. K. Łeńskiej-Bąk, Opole 2015, s. 163-176; taż, Wetter und Krankheit: die meteorologische Beobachtungen an der Universität Wilna in den Jahren 1804 bis 1843, w: Von Kometen, Windhosen, Hagelschlag und Wetterballons: Beiträge zur Geschichte der Meteorologie, hrsg. von I. Kästner, J. Kiefer, Aachen 2014, s. 199-212; taż, Niemiecka medycyna niematerialistyczna 1797-1848 wświetle historiografii z lat 1811-2014, w: Kontynuacja i zmiana. Historiografia krajów Europy Srodkowo-Wschodniej wobec nowych tendencji w nauce XIX-XXI wieku, pod red. Z. Romka [w druku]. 
Nie bez znaczenia dla zmiany jej obrazu pozostawało doskonalenie metod badawczych historii. Wcześniej badania koncentrowały się wyłącznie na źródłach stworzonych przez koryfeuszy tej epoki ${ }^{17}$, podczas gdy od początku XX wieku zaczęto się interesować również poglądami poszczególnych lekarzy zarówno związanych ze środowiskiem akademickim, jak i pracujących poza nim, ale wyrażających swoje opinie w publikacjach. Pół wieku analizy tego rodzaju piśmiennictwa przyczyniło się do utrwalenia pojęcia „niemiecka medycyna romantyczna" już bez uprzednio jej nadawanego pejoratywnego znaczenia, na co nie bez wpływu pozostawało powstanie w rodzimej historiografii nurtu neoromantycznego, którego przedstawiciele uznawali się za spadkobierców romantyków.

Po 1945 roku pojęcie to pozostało w użyciu i nadal jest stosowane w historiografii niemieckiej. Okazało się bowiem przydatne w dominującym po drugiej wojnie światowej standardzie badań kulturowych, który uznawał za niemożliwe wypreparowanie nauk przyrodniczych $\mathrm{z}$ otaczającego je kulturowego kontekstu. Obecność elementów związanych z protestancką metafizyką, niemiecką filozofią idealistyczną i rodzimą tradycją literacką została uznana za zjawisko naturalne w tym samym stopniu, co obecność metafizyki katolickiej, filozofii o katolickim rodowodzie ideowym i tradycji literackiej związanej z kulturą francuską w standardzie głównego nurtu modernizacyjnego europejskiej medycyny klinicznej w tym okresie ${ }^{18}$. Niezwykle obszerna spuścizna piśmiennicza tego okresu (w granicach Rzeszy Niemieckiej działało w pierwszej połowie XIX wieku prawie sto uniwersytetów, w których strukturze funkcjonowały wydziały lekarskie, a z każdym z nich związane było przynajmniej jedno czasopismo specjalistyczne, czasopisma medyczne wydawały również towarzystwa naukowe i różnego rodzaju fundacje) oraz różnice w standardzie metodologicznym, inspirującym badania historyczne nad tą epoką doprowadziły do wystąpienia w poświęconej jej historiografii trwałych i niedających się usunąć sprzeczności.

Różnice dotyczą takich zagadnień, jak cezury tej epoki, liczba występujących w niemieckiej medycynie romantycznej teoretycznych nurtów, zasięg ich wpływów, przyczyny eliminacji różnych nurtów i w ogóle całego romantycz-

17 Analogicznie do historiografii, w której badania długo ograniczano do dokumentów urzędowych wydawanych przez władze, a także do analizy źródeł stworzonych przez władców, przedstawicieli społecznych elit i dowódców. lightenment of the Eighteenth Century, Cambridge 1990; L.S. King, The Philosophy of Medicine. The Early Eighteenth Century, London 1978. 
nego standardu z niemieckiej medycyny klinicznej ${ }^{19}$. Odrzucając występującą wcześniej w historiografii narrację, krytycznie oceniającą poglądy zwolenników standardu niemieckiej medycyny romantycznej jako fałszywe (bo pozbawione realnego odniesienia przedmiotowego), a związku z tym nienaukowe, we współczesnych badaniach nad tą epoką szuka się odpowiedzi na pytanie, dlaczego ów standard w ogóle znalazł zwolenników, przez kogo był popierany, a przez kogo zwalczany, dlaczego utrzymał się na uniwersytetach tak długo i czym można tłumaczyć jego nagłe $z$ nich usunięcie.

Przedstawię skrótowo odpowiedzi na te pytania, odsyłając zainteresowanych do moich prac umieszczonych w przypisach do niniejszego tekstu. Najważniejsze jest to, że niemieccy lekarze ze szkoły romantycznej odrzucili europejski standard modernizacyjny medycyny klinicznej, ponieważ uznali go za sprzeczny z podstawami światopoglądowymi luteranizmu, z tradycją rodzimej filozofii idealistycznej oraz rodzimym dziedzictwem medycyny, sięgającym nie tylko pierwszej połowy XVIII stulecia, lecz czasów średniowiecza i reformacji. Dla niemieckich zwolenników medycyny romantycznej zasadniczą osią organizującą ich własny standard kliniczny były poglądy Martina Lutra i rodzima filozofia idealistyczna (w tym szczególnie Friedricha Wilhelma Schellinga), a wszystko to, co było z nimi sprzeczne, należało usunąć albo przynajmniej zmarginalizować. W praktyce oznaczało to eliminację pewnych obszarów uznawanych za nieistniejące (takich jak np. pojęcie materii) oraz zakaz i krytykę wykonywania badań prowadzonych wewnątrz tych obszarów (np. statystyki medycznej, badań mogących doprowadzić do wniosków o rozprzestrzenianiu się chorób epidemicznych za pośrednictwem materialnych drobin, contagiów i in.). Oznaczało to także wprowadzanie na uniwersytety koncepcji nieuznawanych w pozostałych krajach Europy za odnoszące się do realnie istniejącej rzeczywistości (np. koncepcji odwołującej się do analogii makrokosmosu i mikrokosmosu, hierarchii bytów, które ulegają procesowi metamorfozy, uznania duszy za element sprawujący kontrolę nad przebiegiem procesów fizjologicznych i patologicznych) oraz metod diagnostyki i terapii, tworzonych w sposób dostosowany do obrazu rzeczywistości uznawanego za realny przez lekarzy romantyków (np. uznania zdolności pacjenta do samodzielnego diagnozowania choroby, na którą cierpi, i określania właściwych metod terapii po uprzednim wprowadzeniu tegoż pacjenta przez lekarza w stan snu somnambulicznego; leczenia moralnego pacjentów chorych psychicznie; leczenia bodźcowego wszystkich chorób za pomocą oddziaływania na pobu-

19 Przedstawiam to zróżnicowanie w piśmiennictwie w rozdziale Obraz epoki w piśmiennictwie XIX i XX stulecia. Podsumowanie i wnioski w przywoływanej już książce Niemiecka medycyna romantyczna (s. 111-120). 
dzalność mającą być cechą organizmów, niezależną od materialnego składu leku, ale od siły bodźca, którym lekarz u pacjenta wywołuje reakcję etc.).

Odrzucając europejski standard kliniczny, niemieccy lekarze ze szkoły romantycznej uznawali, że medycyna nie może być rozumiana jako nauka o procesach zachodzących w ludzkim organizmie, definiowanym w sposób naturalistyczny, ponieważ odrzucali samo pojęcie organizmu jako takie, a naturalizm medyczny prowadzący do ukształtowania tak zwanej medycyny somatycznej uznawali za błędną i szkodliwą ideologię. Przyjmowali za realistyczną wizję świata nacechowaną antropomorfizmem. Twierdzili, że świat jest Jednością, Całością, żywym organizmem (Lebendige Ganze) ${ }^{20}$, a wszystkie tworzące go elementy istnieją $\mathrm{w}$ jakimś celu. Nie można ich więc rozpatrywać osobno, ale zawsze poszukując ich związku w celowym porządku Całości. Osnową świata są idee, tworzące wzorce (Urtypen) wszystkiego, co okresowo istnieje. To, co czasowo istnieje i może być postrzegane za pośrednictwem zmysłów, było przez zwolenników standardu romantycznego pojmowane jako przejaw (w dziewiętnastowiecznej polszczyźnie: „zjawienie”) tychże idei, a nie samodzielnie istniejący obiekt, obdarzony realnie występującymi i dającymi się zbadać empirycznie cechami. Tak radykalna różnica w postrzeganiu faktycznej natury świata uniemożliwiała porozumienie między lekarzami ze szkoły romantycznej a zwolennikami europejskiego standardu klinicznego, którzy jego obraz - uznawany za realistyczny przez romantyków - uważali za absurdalny. W pojęciu europejskich klinicystów świat był obszarem, w którym znajdowały się i poruszały pojedyncze materialne obiekty, między którymi występowały pewnego rodzaju relacje. Położenie i kierunek ruchu tych obiektów, a także ich właściwości fizyczne i chemiczne podlegały prawom natury. Obiekty te istniały samodzielnie, a dla wyjaśnienia ich istnienia i struktury nie było konieczne odwoływanie się do niematerialnych idei ani prawzorców (Urtypen), ale do czynników naturalnych, które można i trzeba było badać. Świat europejskich klinicystów był więc światem fizykalnym, to jest poddającym się badaniom fizycznym według kwestionariuszy badawczych samodzielnie ustalanych przez indywidualny podmiot poznający, który występował wobec tego świata w pozycji obserwatora. Każde twierdzenie naukowe, ponieważ było koncepcją o ludzkiej proweniencji, mogło być zagrożone błędem. $Z$ tego tytułu należało dokładnie precyzować warunki obser-

Szerzej przedstawia te kwestie, wraz z obszerną filozoficzną literaturą przedmiotu, Leon Miodoński w monografii Całość jako paradygmat rozumienia świata $w$ myśli niemieckiej przełomu romantycznego. Analiza wybranych problemów (Wrocław 2001). Piszę też na ten temat w monografii Niemiecka medycyna romantyczna, przedstawiając analizę historyczną kształtowania się tego rodzaju wizji świata. 
wacji, przeprowadzać badania i doświadczenia wielokrotnie, a ich wyniki przedstawiać specjalistom do sprawdzenia. W koncepcji romantycznej nie występowała postać samodzielnego, stojącego wobec natury badacza, ale podmiot zbiorowy: Ludzkość, która dochodziła do poznania świata na drodze dedukcji angażującej zbiorowy zmysł poznawczy (Sensorium Communis). Człowiek znajdował się zawsze wewnątrz obszaru obserwacji, będąc jego elementem, a jego podmiotowość nie była postrzegana jako samodzielna. Wiedza naukowa była udzielana Ludzkości przez Ożywioną Całość (Lebendige Gan$z e$ ), oddziałującą w sposób bezpośredni na Sensorium Communis. Była więc wiedzą pewną i opartą na prawdzie, o ile została przez ludzi prawidłowo odebrana. Tak opisany proces poznawczy czynił poszczególne teorie i doktryny medyczne niefalsyfikowalnymi, ponieważ nie zawierał żadnych kryteriów falsyfikacji wiedzy przekazywanej Ludzkości bezpośrednio przez Lebendige Gan$z e$. Podejmowane przez dwa pokolenia niemieckich lekarzy próby sfalsyfikowania kolejnych romantycznych teorii i doktryn nie były możliwe do przeprowadzenia, ponieważ przemawiające na ich niekorzyść dowody empiryczne uznawano za nieprowadzące do konkluzywnych wniosków. Poznanie empiryczne docierało bowiem tylko do odbić / przejawów obiektywnych idei (Erscheinungen), które same w sobie mogły być niedoskonałe, co nie przekreślało jednakże doskonałości samej idei. Postulowane przez europejskich klinicystów realne cechy materialnych obiektów (Eigenschaften) niemieccy romantycy medyczni uważali za złudę, odmawiali bowiem realnego istnienia materii, co uniemożliwiało podejmowanie dyskusji. O ile dla europejskich klinicystów stanem naturalnym była równowaga organizmu, a proces chorobowy uznawali za jej naruszenie - albo przez bodźce zewnętrzne, albo w wyniku zaburzeń w funkcjonowaniu ludzkiego ustroju - o tyle dla lekarzy ze szkoły romantycznej stanem naturalnym był nieustanny proces metamorfozy, w którym poszczególne przejawy Ożywionej Całości wznosiły się ku wyższym poziomom bytu. Ustanie przemian i osiągnięcie równowagi uważali za śmierć danego indywiduum albo większego układu, do którego owo indywiduum należy. O ile więc dla klinicystów celem terapii było zdrowe, długie i owocne życie, to dla romantyków celem ludzkiego życia, o którym lekarz nigdy nie powinien zapominać, była śmierć, która umożliwi człowiekowi przejście na wyższy poziom bytu. Dla tych pierwszych śmierć była medycznym problemem do rozwiązania, możliwe było postawienie pytania, czy i w jaki sposób można zapobiegać jej wystąpieniu w czasie uważanym za przedwczesny, to jest przed osiągnięciem siedemdziesiątego roku życia. Dla zwolenników standardu romantycznego, przyjmujących tę samą długość życia za optymalną, powinno być ono podzielone na dwa okresy, rozdzielone obiektywnie istnie- 
jącą cezurą. W pierwszym okresie, którego granicą jest trzydziesty piąty rok życia, człowiek powinien realizować swoje zobowiązania wobec Gatunku i Ludzkości, to jest zdobyć wykształcenie i środki do życia, założyć rodzinę oraz spłodzić dzieci. Po trzydziestym piątym roku życia powinien zwrócić swoje zainteresowania ku wieczności i nie domagać się aktywnej terapii w tych wypadkach, w których wydaje się beznadziejna. Należało tę sytuację rozpatrywać jako wyrok Opatrzności, zgodnie z którym człowiek wypełnił na ziemi swoje powołanie i może już przejść do życia pozaziemskiego, gdzie spotka go nagroda lub kara.

Szczegółowe omówienie standardu niemieckiej medycyny romantycznej przekracza ramy tego opracowania, już jednak jego pobieżna prezentacja ukazuje różnice $\mathrm{z}$ opartym na podstawach empirycznych europejskim standardem klinicznym. Niemiecki standard romantyczny był od 1797 do 1848 roku aktywnie narzucany niemieckim uniwersytetom przez władze Prus i innych niemieckich państw protestanckich, zmierzających do wyparcia z nauki wszelkich pozostałości filozofii Oświecenia, w której upatrywano genezy europejskiego standardu klinicznego. Podstawą tych działań było dążenie do zapobieżenia rozprzestrzenianiu się idei oświeceniowych, które konserwatywne władze Prus i pozostających pod ich wpływem protestanckich państw niemieckich uznały za zdolne do rozsadzenia spójności państwa i wybuchu rewolucji. Władze te nie dostrzegały, że realnym czynnikiem, który mógł w latach 1830-1848 doprowadzić do zamieszek, wybuchu rewolucji i obalenia dotychczasowych struktur władzy, stały się postępująca pauperyzacja szerokich rzesz ludności i związane $\mathrm{z}$ nią radykalne pogorszenie sytuacji epidemiologicznej. Klęski elementarne (powodzie z lat trzydziestych, a przede wszystkim czterdziestych), ze względu na ogrom strat materialnych, doprowadziły do wybuchu masowych epidemii tyfusu i cholery, które pochłonęły dziesiątki tysięcy ofiar. Niematerialistyczny standard interpretacyjny niemieckiej medycyny romantycznej powodował, że te metody, które w dziewiętnastowiecznej Europie od dawna były zalecane przez władze innych państw, w Prusach zostały w latach 1830-1848 zarzucone, jeśli gdzieś były w trakcie epidemii stosowane, działo się tak wyłącznie z inicjatywy i na własną odpowiedzialność lekarzy urzędowych, znających ówczesny standard europejskiej medycyny klinicznej i akceptujących jego podstawy. Przyczyną całkowitej bezradności wobec epidemii chorób zakaźnych władz tych państw Rzeszy, które wprowadziły na uniwersytetach standard medycyny romantycznej jako obowiązujący, było wspomniane już odrzucenie przez nie faktu istnienia materii, uzasadniane przez rodzimych filozofów. Za istotę choroby uznano w standardzie romantycznym niematerialną ideę, która opanowywała niematerialną podstawę 
ludzkich ciał, to jest ich duszę. Zgodnie z tą koncepcją tworzenie kwarantanny, izolacja osób już zarażonych i inne działania stosowane w Europie przez lekarzy miejskich, podejmowane $\mathrm{w}$ celu ograniczenia rozprzestrzeniania się chorób zakaźnych przez zapobieganie kontaktu ludzi zdrowych z już zarażonymi i ich rzeczami osobistymi, zostały uznane za irracjonalne. Ci spośród niemieckich profesorów, którzy próbowali w swoich pracach nawiązać do europejskiego standardu klinicznego i uznawali przed 1848 rokiem możliwość rozprzestrzeniania się epidemii przez drobne materialne czynniki zakaźne, jak na przykład Jakob Henle, zostali poddani krytyce przez zwolenników medycyny romantycznej. Do jego poglądów powrócono w medycynie niemieckiej dopiero po odkryciach Ludwika Pasteura, który wykazał doświadczalnie nie tylko istnienie żywych mikroorganizmów, lecz także ich rolę jako wyspecjalizowanych patogenów, to jest czynników odpowiedzialnych za powstawanie jednej jednostki chorobowej. W tym kontekście cała patologia związana $\mathrm{z}$ akademickim standardem niemieckiej medycyny romantycznej, oparta na rodzimej filozofii idealistycznej, ukazywała się jako absurdalna, hamująca możliwość skutecznego rozwiązania podstawowego problemu medycyny klinicznej w XIX stuleciu, jakim była ogromna śmiertelność z powodu ostrych chorób zakaźnych oraz zakażenie poważnej części ówczesnej europejskiej populacji chorobami o przebiegu przewlekłym (gruźlica oraz kiła). Stanowcze odrzucenie przez władze protestanckich państw niemieckich standardu medycyny romantycznej i jego usunięcie z uniwersytetów drogą administracyjną w 1849 roku były spełnieniem postulatów wyrażanych od lat trzydziestych przez niemieckie środowisko lekarskie, które poddawało ów standard nasilającej się krytyce zarówno podczas zjazdów Niemieckiego Towarzystwa Lekarzy i Przyrodników, jak i w dyskusjach publicznych, szczególnie po katastrofalnej epidemii cholery, która spustoszyła wiele regionów Niemiec w latach 1831-1832. Krytyka ta nie została jednak wówczas przyjęta przez władze, a jej skutkiem było nawet nasilenie irracjonalnych tendencji w niemieckim przyrodoznawstwie akademickim. Dopiero klęski elementarne i epidemie z lat czterdziestych XIX wieku przyczyniły się do takiej radykalizacji niemieckiego środowiska lekarskiego, że w trakcie Wiosny Ludów udało się doprowadzić do dymisji aprobujących standard romantyczny akademików i do obsadzenia wydziałów lekarskich zwolennikami europejskiego standardu klinicznego. Był on większości niemieckich lekarzy znany zarówno z lektur i obserwacji z podróży po Europie, jak i z przekazu tych profesorów, których poglądy były zbieżne z europejskim standardem klinicznym. Podsumowując, niemiecki standard romantyczny panujący na uniwersytetach między 1797 a 1848 rokiem należy uznać za ślepą uliczkę w rozwoju europejskiej medycyny klinicznej, a pod- 
stawową przyczyną tej oceny jest podporządkowanie efektywności medycyny względom światopoglądowym.

Podstawowym pytaniem, jakie nasuwa się - po z konieczności skrótowym przedstawieniu standardu niemieckiej medycyny romantycznej - jest kwestia, dlaczego ta struktura poznawcza i praktyczna miałaby zostać przyjęta w polskim środowisku akademickim jako oparta na realistycznym oglądzie świata, a dostosowane do tego oglądu teorie i doktryny medyczne miałyby zostać uznane za racjonalne, oparte na podstawach faktycznych i oferujące efektywne metody terapii. Jako uzasadnienie pozytywnej recepcji standardu medycyny romantycznej nie mogły służyć przesłanki metafizyczne, ponieważ polskie środowisko lekarskie składało się w większości z katolików, podobnie jak w społeczeństwie zamieszkałym w granicach Rzeczpospolitej odsetek luteran nie był wśród lekarzy zbyt wysoki. Do pozytywnej recepcji standardu romantycznego nie mogły przyczynić się także względy polityczne. W okresie sprawowania władzy nad Warszawą przez Prusy nie było w niej jeszcze uniwersytetu, a w założonym pod pruską kuratelą Warszawskim Towarzystwie Przyjaciół Nauk dominowali zwolennicy ideologii Oświecenia. Na Uniwersytecie Krakowskim od przełomu XVIII wieku aż do końca okresu rozbiorów dominowały wpływy medycyny wiedeńskiej, której przedstawiciele zdecydowanie przeciwstawiali się upowszechnianiu standardu medycyny romantycznej w Europie. Medycyna na Uniwersytecie Wiedeńskim była wykładana zgodnie $\mathrm{z}$ europejskim standardem klinicznym, a sam Wiedeń należał do głównych ośrodków upowszechniania tego standardu w Europie. Na uniwersytetach działających w zaborze rosyjskim - w Warszawie i Wilnie - podstawą dydaktyki również był europejski standard kliniczny. Był on wykładany w Warszawie jeszcze przed powołaniem tu Uniwersytetu, w Szkole Medyko-Chirurgicznej pozostającej pod wpływem medycyny francuskiej, a po likwidacji Uniwersytetu był podtrzymywany w tutejszym środowisku lekarskim do $1857 \mathrm{roku}$, to jest do powołania Akademii Medyko-Chirurgicznej. Na Uniwersytecie Wileńskim od 1803 do 1832 roku był oceniany krytycznie, ponieważ wileński Wydział Lekarski należał do głównych ośrodków upowszechniania europejskiego standardu klinicznego w tym okresie. Także po likwidacji uczelni, w utworzonej z jej części Akademii Medyko-Chirurgicznej, był oceniany negatywnie aż do 1838 roku, co wiązało się z obsadzeniem większości katedr przez zwolenników europejskiego standardu klinicznego. Tylko w latach 1838-1841 obserwujemy próby popularyzacji standardu romantycznego w Wilnie przez profesorów kilku przedmiotów, przybyłych wówczas z Niemiec, ale pró- 
by te były skutecznie torpedowane przez pozostałych członków tutejszej Rady Wydziału.

W związku z tak zgodną krytyczną opinią polskiego środowiska akademickiego, dotyczącą standardu niemieckiej medycyny romantycznej, wszystkie występujące w polskim piśmiennictwie publikacje, których autorami byli lekarze, utrzymane w duchu przychylnym standardowi niemieckiej medycyny romantycznej, wychodziły spod pióra autorów niezwiązanych ze środowiskiem akademickim lub pozostających $\mathrm{z}$ tym środowiskiem $\mathrm{w}$ otwartym sporze. Większość $\mathrm{z}$ nich była całkowicie ignorowana przez polskie czasopisma medyczne, a dotyczące zwolenników medycyny romantycznej przekazy źródłowe możemy znaleźć w czasopismach przeznaczonych dla mało wyrobionego odbiorcy. Te z nich, które próbowały uzyskać status periodyków naukowych, spotykały się ze zmasowaną krytyką ze strony poważnych polskich periodyków medycznych, co prowadziło do likwidacji czasopism nawiązujących do standardu romantycznego z powodu wykruszania się prenumeratorów. Przykładem tego rodzaju działań podejmowanych przez opiniotwórcze czasopismo lekarskie może być publikacja przez warszawski „Tygodnik Lekarski” cyklu krytycznych recenzji czasopisma „Przyjaciel Zdrowia”, popularyzującego treści niezgodne ze standardem klinicznym. Do 1863 roku żaden z działających na ziemiach polskich uniwersytetów nie stworzył dogodnej bazy instytucjonalnej dla popularyzowania niemieckiego standardu romantycznego, pozostał on w związku z tym doktryną pozaakademicką, a jego nieliczni zwolennicy plasowali się w obrębie tak zwanej medycyny alternatywnej.

Ocena standardu niemieckiej medycyny romantycznej została w polskich ośrodkach akademickich ukierunkowana przez rodzimą tradycję filozficzną o rodowodzie oświeceniowym, oddziałującą w XVIII i w pierwszej połowie XIX wieku na świadomość krajowych elit ${ }^{21}$, i przez poglądy dwóch wybitnych klinicystów - Josefa Franka ${ }^{22}$ i Jędrzeja Śniadeckiego ${ }^{23}$, zgodne ze standardem głównego nurtu modernizacyjnego medycyny klinicznej w Europie. Ten pierwszy, absolwent Uniwersytetu Wiedeńskiego i syn jednego z najwybitniejszych

21 Por. B. Płonka-Syroka, An Overview of the Polish School of Medical Philosophy from the $19^{\text {th }}$ Century to Today, "Journal of Pharmacy and Pharmacology” 2014, no 2, s. 509-526.

22 Por. taż, Rola Józefa Franka w kształtowaniu standardu polskiej medycyny klinicznej w latach 1805-1830, w: Sasiedztwo i granica: medycyna, historia i kultura $w$ dialogu polsko-niemieckim / Nachbarschaft und Grenze: Medizin, Geschichte und Kultur im Polnisch-Deutsch Dialog, pod red. B. Płonki-Syroki i F. Drossa, Wrocław 2010, s. 161-175.

23 Por. taż, Jędrzej Śniadecki wobec brownizmu - kontekst kulturowy i podstawy teoretyczne krytyki doktryny Johna Browna, Życie codzienne w XIX wieku i jego wptyw na stan zdrowia ludności, pod red. B. Płonki-Syroki i A. Syroki, Wrocław 2003, s. 549-568. 
klinicystów drugiej połowy XVIII wieku, Johanna Petera Franka ${ }^{24}$, przed przyjazdem w 1804 roku do Wilna i objęciem w 1805 roku kierownictwa Kliniki Lekarskiej tutejszego Wydziału Lekarskiego (które sprawował do 1823 roku) odbył podróż naukową po Europie, będąc wykładowcą kilku uniwersytetów włoskich. Ten drugi, absolwent Uniwersytetu Jagiellońskiego i brat rektora tej uczelni, wybitnego fizyka Jana Śniadeckiego, późniejszego rektora Uniwersytetu w Wilnie, przed objęciem w 1804 roku Katedry Chemii na Wydziale Lekarskim Uniwersytetu Wileńskiego również podróżował po Europie, zapoznając się ze standardem drugiego po Wiedniu ośrodka ówczesnej medycyny klinicznej - Edynburga. Podstawy teoretyczne poglądów klinicznych obydwu uczonych były wspólne - cechowało je naturalistyczne i somatyczne ujęcie procesów życiowych oraz walka $\mathrm{z}$ wszelkimi przejawami irracjonalizmu ${ }^{25}$. Jego krytykę przedstawiali zarówno w publikacjach, jak i w dydaktyce, a wpływy ich wykładów utrzymały się w polskim środowisku lekarskim przez następne pokolenie ${ }^{26}$. Podobnie krytyczne stanowisko wobec standardu niemieckiej medycyny romantycznej zajmowali pozostali profesorowie wileńscy. Wbrew stworzonej przez poetów „czarnej legendzie” wileńskich klinicystów, którym zarzucano trwanie przy standardzie o rodowodzie oświeceniowym i zamykanie się na nowe impulsy czerpane z romantycznej nauki niemieckiej (w tym np. popularną ówcześnie koncepcję mesmeryzmu), wileńscy studenci medycyny uważali swych nauczycieli za autorytety, a przekazywaną przez nich wiedzę za nowoczesną i opartą na faktach, co potwierdzają nowe badania źródłowe. W publikacjach klinicznych, kazuistycznych i podręcznikach z lat 1805-1832 możemy odnaleźć nawiązanie do najbardziej nowatorskich tendencji w ówczesnej medycynie światowej, które były aprobatywnie przedstawiane wileńskim studentom. Standard medycyny wileńskiej z omawianego

24 Por. Ch. Probst, Johann Peter Frank als Arzt am Krankenbett, „Sudhoffs Archiv für Geschichte der Medizin” 1975, s. 20-53; H. Breyer, Johann Peter Frank: „Fürst unter den Ärzten Europas", Leipzig 1983.

25 Por. B. Płonka-Syroka, Recepcja homeopatii w polskiej myśli medycznej XIX stulecia, „Kwartalnik Historii Nauki i Techniki” 2001, nr 1, s. 7-27; taż, Postawy lekarzy polskich generacji 1830-1850 wobec homeopatii i ich społeczne uwarunkowanie, w: Szkice z socjologii medycyny, pod red. M. Libiszowskiej-Żółtkowskiej, M. Ogryzko-Wiewiórowskiej i W. Piątkowskiego, Lublin 1998, s. 85-99.

26 Por. taż, Die Rezeption der medizinische Lehre von John Brown in der polnischen akademischen Medizin an der Wende vom 18, zum 19. Jahrhundert, w: Heilkunde und Heilmittel. Zum Erwerb und Transfer von medizinisch-pharmazeutischen Wissen in Europa, hrsg. von J. Kiefer, Aachen 2013, s. 193-206; taż, Międzykulturowa recepcja doktryn medycznych na przykładzie doktryny Johna Browna (1736 -1788). Problemy metodologiczne, „Kwartalnik Historii Nauki i Techniki” 1993, nr 4, s. 3-37. 
okresu należał do najnowocześniejszych w Europie i można go zestawić z poziomem najpoważniejszych ówczesnych szkół klinicznych w Wiedniu, Paryżu i Edynburgu. Poglądy i oceny aktualnych kwestii medycznych wyrażane przez wileńskich klinicystów - Josefa Franka i Jędrzeja Śniadeckiego - ukształtowały standard kliniczny medycyny polskiej w całym XIX stuleciu. Ich krytyczne nastawienie do niemieckiej medycyny romantycznej zostało przyjęte na uniwersytetach w Krakowie i Warszawie, co stworzyło barierę dla upowszechnienia się koncepcji romantycznych w polskim środowisku lekarskim zarówno w pierwszej, jak i w drugiej połowie XIX wieku, gdy na jej podstawie zaczął się kształtować standard tak zwanej medycyny alternatywnej. Ci z lekarzy polskich albo spośród praktykujących na ziemiach polskich obcokrajowców, którzy ulegali inspiracjom czerpanym z niemieckiej medycyny romantycznej, bywali skazywani na ostracyzm polskiego środowiska lekarskiego, w tym zarówno akademików, jak i lekarzy praktyków, a ich postawa bywała piętnowana jako przejaw szarlatanerii, partactwa i działania z żądzy zysku, opartego na mamieniu pacjentów niemożliwymi do spełnienia obietnicami.

Dla przedstawienia wpływu, jaki poglądy profesorów Franka i Śniadeckiego wywarły na ich następców i uczniów, przywołajmy dwa cytaty. Jeden z wileńskich absolwentów, doktor Karol Kaczkowski, tak pisał w 1845 roku o kierowniku wileńskiej kliniki lekarskiej z lat 1805-1823:

Tej wszechstronnej wyrozumiałości Franka winniśmy, że magnetyzm zwierzęcy ${ }^{27}$, jego działanie na ciało ludzkie, jego cudowne zjawiska, ukryte gdzie indziej nieprzejrzaną dla uczniów zasłoną, nie były nam obce. Śmielej tedy wpatrywaliśmy się w praktyczne fakta, bo wiedzą przewodnika oświeceni cudownościami nie obałamucaliśmy się, ale na drodze doświadczenia i obserwacji wielkich działaczy natury śledziliśmy. ${ }^{28}$

Zastosowana przez profesora Franka metoda weryfikacji empirycznej odnosiła się nie tylko do popularnego w niemieckiej medycynie romantycznej mesmeryzmu, ale do wszystkich aktualnych w ówczesnej medycynie klinicznej koncepcji, które były nie tylko omawiane ze studentami, lecz także poddawane wspólnie z nimi ocenie praktycznej. Poglądy metodologiczne profesora Franka, przedstawiane w podręcznikach jego autorstwa i artykułach opublikowanych na łamach wileńskiego „Dziennika Chirurgii Medycyny i Farmacji” cechuje nowatorstwo i innowacyjność, co znalazło odbicie w jego krytycznym stanowisku wobec standardu niemieckiej medycyny romantycz-

27 Jedna z głównych koncepcji popularyzowanych w standardzie romantycznym, będąca podstawą wielu teorii i doktryn medycznych. Por. B. Płonka-Syroka, Mesmeryzm. Od astrologii do bioenergoterapii, Wrocław 2007.

28 Por. K. Kaczkowski, Odpowiedź na list p. Kwestarza Somnambula, „Athenaeum” 1845, t. 4 , s. 210. 
nej, który uznał za oparty na spekulacjach ${ }^{29}$.

Podobnie, wysoka ocena zdolności naukowych i dydaktycznych została wystawiona w 1851 roku profesorowi Śniadeckiemu, kierującemu wileńską kliniką lekarską w latach 1826-1838, a wcześniej wykładowcy chemii na Wydziale Lekarskim, przez jednego z jego wychowanków, późniejszego profesora Uniwersytetu Wileńskiego, Adama Adamowicza ${ }^{30}$. Według Adamowicza, Śniadecki już w 1812 roku był bliski pozytywnego zweryfikowania hipotezy zakaźnego charakteru chorób epidemicznych przez czynniki związane z żywą materią organiczną. Zaobserwował bowiem w trakcie odwrotu armii napoleońskiej spod Moskwy, że epidemia tyfusu szerzy się wyłącznie wzdłuż dróg komunikacyjnych, którymi przemieszczały się dotknięte ową epidemią wojska, a nie występuje w pobliskich nawet miejscowościach i osadach, do których zarażone tyfusem wojska nie dotarły. Stwierdzenie tego rodzaju pozwalało obalić występującą w medycynie od czasów starożytnych hipotezę, zgodnie z którą epidemie szerzą się drogą powietrzną przez niematerialne miazmaty. Śniadecki mógł wykazać, że jest to hipoteza błędna. Podobne poglądy dotyczące przyczyn epidemii na Litwie wypowiadał w tym samym czasie także profesor Frank, co oznaczało, że głoszone przez zwolenników standardu niemieckiej medycyny romantycznej poglądy o rozprzestrzenianiu się epidemii za pośrednictwem niematerialnej idei choroby były przez nich uznawane za absurdalne. Nie znaczy to jednak, że nie były dyskutowane - w katalogach biblioteki uniwersyteckiej w Wilnie zachowały się bowiem liczne tytuły podręczników medycyny klinicznej, których autorami byli najważniejsi autorzy związani ze standardem romantycznym. Wileńscy studenci mogli sobie wyrobić własne zdanie na temat niemieckiego standardu romantycznego nie tylko na podstawie słów profesora, lecz także podczas przeprowadzanych pod jego opieką doświadczeń klinicznych, dających podstawę do samodzielnej krytycznej lektury współczesnych dzieł medycznych. Pomocą w zajęciu stanowiska wobec irracjonalnych romantycznych doktryn medycznych, niezgodnych z doświadczeniem klinicznym, za to opartych na spekulacji, mogły służyć wileńskim studentom artykuły w tamtejszej prasie medycznej pisane przez profesorów ${ }^{31}$, jak również tłumaczenia prac autorów związanych z eu-

29 Szerzej na ten temat piszę w pracy Medycyna niemiecka nurtu niematerialistycznego... (s. 397-402).

30 Por. A. Adamowicz, Wiadomość o chorobach postrzeganych dawniej w Litwie w ogólności, a w szczególności $w$ Wilnie lub jego okolicach od r. 1826, z dodaniem postrzeżeń meteorologicznych, „Pamiętnik Towarzystwa Lekarskiego Warszawskiego” 1851, t. 1, s. 13-119. Por. J. Frank, Rzut oka na dzisiejszy stan medycyny praktycznej, „Dziennik Medycyny, Chirurgii i Farmacji” 1822, t. 1, z. 1, s. 1-31; tenże, O wpływie ducha systematu w medy- 
ropejskim nurtem klinicznym, występujących w roli autorytetów ${ }^{32}$. Przez niemal cztery dekady swojej pracy dydaktycznej na wileńskim Wydziale Lekarskim Śniadecki prowadził nauczanie w europejskim duchu klinicznym. Zarówno w dydaktyce, jak i w publikacjach wyrażał wobec niemieckiej medycyny romantycznej stanowisko krytyczne ${ }^{33}$.

Podobne metody nauczania klinicznego stosowane były przez profesorów kliniki lekarskiej Uniwersytetu Krakowskiego. Jeden z nich, Józef Maciej Brodowicz, tak pisał w pamiętniku na temat niemieckiej medycyny romantycznej:

Wnet jednak poczęli Niemcy nabijać brownizm na kopyto filozofii natury Schellinga na szczęście w tak mistyczny język ubranej, iż go tylko szczupła liczba adeptów zrozumieć była w stanie, resztę zaś odstraszyły od zgłębiania tych misteriów niefortunne rezultaty terapii, na jej zasadach zbudowanej. ${ }^{34}$

Podobnie jak profesorowie wileńscy, Brodowicz analizował ze studentami aktualne poglądy kliniczne, oceniając je zgodnie z naturalistyczno-somatycznym standardem głównego nurtu ówczesnej medycyny i wraz z innymi profesorami poddając testom klinicznym ${ }^{35}$. Niektórzy absolwenci wydziałów lekarskich w Wilnie i Krakowie obierali nawet wybrane zagadnienia związane ze standardem niemieckiej medycyny romantycznej jako tematy doktoratów. Zawsze jednak konkluzje końcowe zawierały negatywne oceny tego standardu ${ }^{36}$. Ta sama sytuacja występowała w Warszawie, w której niemiecki standard romantyczny przedstawiano studentom ${ }^{37}$ jako jedną $\mathrm{z}$ aktualnych kon-

cynie, „Dziennik Medycyny, Chirurgii i Farmacji” 1822, t. 1, z. 4, s. 589-592; tenże, O magnetyzmie zwierzęcym, „Dziennik Medycyny, Chirurgii i Farmacji” 1822, t. 1, z. 2, S. $193-214$.

32 Por. Ch. W. Hufeland, Magnetyzm, „Pamiętnik Magnetyczny Wileński” 1817, t. 2, s. 326-330. Prace Hufelanda tłumaczono na język polski od 1800 do 1870 roku, wielokrotnie wznawiano, a w latach 1815-1830 były zalecane przez władze Królestwa Polskiego do użytku także w szkołach średnich.

33 Szerzej o poglądach Śniadeckiego w sprawie niemieckiej medycyny romantycznej pisałam w pracach Medycyna niemiecka nurtu niematerialistycznego... (s. 402-403) oraz Niemiecka medycyna romantyczna (s. 445-459). Ogólnie o stanowisku lekarzy wileńskich wobec niemieckiego standardu medycznego por. B. Płonka-Syroka, Medycyna niemiecka nurtu niematerialistycznego..., s. 395-418.

34 J.M. Brodowicz, Pamiętnik ogólny swojego zawodu lekarskiego i nauczycielskiego, Kraków 1871, s. 134.

35 Szerzej na temat recepcji standardu niemieckiej medycyny romantycznej w Krakowie: B. Płonka-Syroka, Medycyna niemiecka nurtu niematerialistycznego..., s. 430-442.

36 Por. np. J. Jaszczurowski, De somno commentario inauguralis physiologico-pathologica, Cracoviae 1839.

37 Szerzej na temat recepcji standardu niemieckiej medycyny romantycznej w Warszawie zob. B. Płonka-Syroka, Medycyna niemiecka nurtu niematerialistycznego..., s. 418-430. 
cepcji medycznych, jednakże poddawano ocenie krytycznej, dla której podstawą był współczesny standard medycyny klinicznej we Francji, a także poglądy współczesnych klinicystów wileńskich - Franka i Śniadeckiego.

Niepomyślną recepcję standardu niemieckiej medycyny romantycznej uwarunkowały więc czynniki światopoglądowe (był ściśle związany z protestancką metafizyką, która katolikom wydawała się sprzeczna $\mathrm{z}$ ich własnym światopoglądem), teoriopoznawcze (był oparty na niemieckiej filozofii idealistycznej, która była postrzegana przez autorów polskich jako zawiła, sztuczna i irracjonalna), praktyczne (doktryny medyczne oparte na romantycznych teoriach medycznych były rażąco nieskuteczne, nawet jak na owe czasy), dydaktyczne (był przedstawiany studentom jako koncepcja niepoddająca się empirycznej weryfikacji, podczas gdy w europejskim standardzie klinicznym właśnie empiryczną weryfikację wiedzy medycznej uznawano za podstawę kształcenia lekarzy) i administracyjne (podczas gdy w protestanckich krajach Rzeszy Niemieckiej standard romantyczny był aktywnie wspierany przez władze, na uniwersytetach polskich w Krakowie, Warszawie i Wilnie nie było tego rodzaju nacisków) ${ }^{38}$. Można więc stwierdzić, że brak zewnętrznych nacisków politycznych i powszechna krytyczna ocena racjonalności i efektywności terapeutycznej oraz uznawanie wizji świata, na której się opierał, za mityczną, stworzyły skuteczne przesłanki niepomyślnej recepcji standardu romantycznego zarówno w polskim środowisku akademickim, jak i wśród lekarzy praktyków oraz studentów, których nie zachęcały do wyboru medycyny romantycznej względy potencjalnej kariery naukowej w państwowych instytucjach akademickich. Wiele przykładów tego typu postawy odnotowywano na uniwersytetach niemieckich, gdyż dla wielu ubogich absolwentów uzyskanie stałej i dobrze płatnej posady uniwersyteckiej warte było akceptacji teorii nieuznawanych nigdzie w Europie za naukowe ${ }^{39}$.

Od końca lat czterdziestych, to jest od czasu jego wyeliminowania $\mathrm{z}$ uniwersytetów niemieckich, standard niemieckiej medycyny romantycznej nie był już poddawany w polskim piśmiennictwie specjalistycznym ani też $\mathrm{w}$ dydak-

38 Poza krótkim okresem w latach 1838-1841, gdy po śmierci cieszącego się wielkim autorytetem naukowym na wileńskim Wydziale Lekarskim Śniadeckiego wykładowcy niemieckiego pochodzenia, zatrudnieni tu po 1832 roku w wyodrębnionej ze zlikwidowanego uniwersytetu Akademii Medyko-Chirurgicznej, usiłowali upowszechniać w Wilnie rodzimy standard romantyczny. Ich starania napotkały jednakże aktywne przeciwdziałania innych członków Rady Wydziału Lekarskiego, wychowanków Franka i Śniadeckiego, którym udało się utrzymać w Wilnie europejski standard kliniczny.

39 O postawach tego typu, jako częstych, pisze Isaiah Berlin (Korzenie romantyzmu. Wy kłady mellonowskie w zakresie sztuk pięknych wygłoszone w Narodowej Galerii Sztuki $w$ Waszyngtonie, red. H. Hardy, przeł. A. Bartkowicz, Poznań 2004, s. 143-175). 
tyce akademickiej krytyce jako jedna z aktualnych koncepcji klinicznych. Jego ocenę przesunięto do obszaru historiografii medycyny, a krytyczne wzmianki na ten temat publikowali zarówno autorzy krajowi ${ }^{40}$, jak i wydawani w tłumaczeniach autorzy zagraniczni ${ }^{41}$. Zastanawiano się w tych publikacjach nad przyczynami wprowadzenia i podtrzymywania na niemieckich uniwersytetach standardu medycyny romantycznej, wskazując jako główną przyczynę naruszenie autonomii niemieckiego środowiska lekarskiego przez czynniki zewnętrzne, na tyle silne, że były zdolne narzucić swoje zdanie akademikom. Wskazywano także, że niemiecki standard romantyczny można uznawać za w większym stopniu odgórnie zadekretowany, aniżeli w praktyce realizowany przez niemieckich lekarzy. Koronnym dowodem na znajomość i akceptację europejskiego standardu klinicznego była bardzo szybka eliminacja pozostałości standardu romantycznego w latach 1849-1850, gdy został on usunięty z uczelni, oraz możliwość zastąpienia dotychczasowej kadry dydaktycznej przez nowych wykładowców o europejskich poglądach.

W drugiej połowie XIX wieku większość polskich studentów odbywających studia medyczne za granicą studiowała na uniwersytetach niemieckich ${ }^{42}$. Spotykali się na nich z krytyczną oceną niemieckiego standardu romantycznego, wyrażaną zarówno przez wykładowców przedmiotów klinicznych, jak i historii medycyny. Była ona jednakże przedstawiana w bardzo skrótowej formie, bez wgłębiania się w szczegółowe analizy doktryny, uznawanej za błędną i opartą na spekulacjach. Stopniowo wśród polskich studentów i lekarzy zanikła wiedza na temat niemieckiego standardu romantycznego, z którą nie można się było zapoznać ani w Niemczech, ani na uniwersytetach innych krajów europejskich, na których ten standard nie był w ogóle omawiany, jako uznawany w całości za irracjonalny. Z czasem zanikła wśród lekarzy polskich także znajomość samego pojęcia „niemiecka medycyna romantyczna”, które nie występuje w publikacjach polskich historyków medycyny aż do lat dziewięćdziesiątych XX wieku.

40 Por. Wykłady historii medycyny Fryderyka Hechlla, spisane przez L. Przybyłkę, rkps w zbiorach Katedry Historii Medycyny i Farmacji Collegium Medicum Uniwersytetu Jagiellońskiego, Dział VIII, nr 2; J. Oettinger, Umiejętność lekarska wobec szkół, a w szczególności wobec urojonej szkoły dawnej i nowej. Badanie historyczno-krytyczno-lekarskie, Kraków 1863.

41 Por. H. Haeser, Historia medycyny, t. 2: Dzieje medycyny nowożytnej, tłum. H. Łuczkiewicz, Warszawa 1886; J. Petersen, Rozwój historyczny terapii lekarskiej, tłum. G. Fritsche, Warszawa 1882.

42 Por. T. Brzeziński, Polskie peregrynacje po dyplomy lekarskie (od średniowiecza po odzyskanie niepodległości w 1918 r.), Warszawa 1999. 
Polską recepcję niemieckiego standardu romantycznego należy wpisać w szerszy kontekst europejski. Wypowiadane przez polskich lekarzy opinie na temat niemieckiej medycyny romantycznej nie były bowiem odosobnione, ale wpisywały się w ramy głównego nurtu medycyny klinicznej w Europie. Podstawy i praktyka tego nurtu były w polskim środowisku lekarskim i akademickim wybierane autonomicznie i oparte na autentycznych preferencjach teoretycznych polskich lekarzy. Zasługuje przy tym na uwagę fakt, że zajmowane przez nich w tej kwestii stanowisko było tak jednolite i silne, że podporządkowywali mu się również lekarze obcego pochodzenia praktykujący na ziemiach polskich, zabiegający o powodzenie wśród pacjentów w tym samym stopniu, co o uznanie swoich kompetencji przez kolegów zrzeszonych w polskich korporacjach lekarskich i publikujących w wydawanych w języku polskim profesjonalnych czasopismach medycznych.

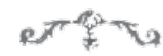

A B STR A C T

German Romantic Medicine (1797-1848)

in Polish Scholars' Opinions Until 1863

German Romantic medicine is an area almost unknown to Polish humanists. The topic had been absent in Polish historiography of medicine until 1989 and the concept had remained unknown. The situation changed in the nineties with an opportunity of long-term research over the European history of science for Polish scholars. The base for the research was both the Western historiography standard and original sources from the era. A monograph published 1999 followed by a second extended edition in 2007 and a series of publications were a result of the research in German libraries conducted as a part of KBN, DAAD and DFG funds. Those publications offered Polish recipients the ideas of German Romantic medicine in their historic and historiographic perspective. The majority of Polish medical students received their Masters or Doctorate diplomas at German universities in nineteenth century so the goal of the research was to investigate an attitude of Polish academia towards the German Romantic standard. It was shown that the attitude was unequivocally negative during the period when this standard was predominant at German universities (1797-1848) and after that in historical analyses. The goal of the article is to present the general characteristic of German Romantic medicine and Polish academia's attitude towards it until 1863.

KEYWORDS

German Romantic medicine, history of clinical medicine, polish reception of German Romantic medicine 